NBER WORKING PAPER SERIES

\title{
SPENDING LESS TIME WITH THE FAMILY: THE DECLINE OF FAMILY OWNERSHIP IN THE UK
}

\author{
Julian Franks \\ Colin Mayer \\ Stefano Rossi \\ Working Paper 10628 \\ http://www.nber.org/papers/w10628 \\ NATIONAL BUREAU OF ECONOMIC RESEARCH \\ 1050 Massachusetts Avenue \\ Cambridge, MA 02138 \\ July 2004
}

This paper has been written for the National Bureau of Economic Research Programme on the History of Corporate Ownership: The Rise and Fall of Great Business Families. We are grateful for helpful suggestions on this and a companion paper ("The Origination and Evolution of Ownership and Control") from participants at conferences at the American Finance Association meetings in Washington DC, January 2003, the National Bureau of Economic Research Programme on the Evolution of Family Ownership conference in Boston, INSEAD and Lake Louise, the Political Economy of Financial Markets Conference at Princeton, September 2003 and the RIETI Conference on Comparative Corporate Governance: Changing Profiles of National Diversity in Tokyo, January 2003, and at seminars at the Bank of England, the Bank of Italy, Cambridge University, the London Business School, the London School of Economics, SNS, Stockholm, the Stern School, New York University, Université Libre de Bruxelles, University of Bologna and UCLA. We have received helpful comments from Brian Cheffins, Barry Eichengreen, Charles Hadlock, Leslie Hannah, Cliff Holderness, Gregory Jackson, Kose John, Hideaki Miyajima, Randall Morck, Hyun Song Shin, Oren Sussman, Elu von Thadden and Xavier Vives. The views expressed herein are those of the author(s) and not necessarily those of the National Bureau of Economic Research.

(C2004 by Julian Franks, Colin Mayer, and Stefano Rossi. All rights reserved. Short sections of text, not to exceed two paragraphs, may be quoted without explicit permission provided that full credit, including (C) notice, is given to the source. 
Spending Less Time with the Family: The Decline of Family Ownership in the UK Julian Franks, Colin Mayer, and Stefano Rossi

NBER Working Paper No. 10628

July 2004

JEL No. G32

\section{$\underline{\text { ABSTRACT }}$}

Family ownership was rapidly diluted in the twentieth century in Britain. The main cause was equity issued in the process of making acquisitions. In the first half of the century, it occurred in the absence of minority investor protection and relied on directors of target firms protecting the interests of shareholders. Families were able to retain control by occupying a disproportionate number of seats on the boards of firms. However, in the absence of large stakes, the rise of hostile takeovers and institutional shareholders made it increasingly difficult for families to maintain control without challenge. Potential targets attempted to protect themselves through dual class shares and strategic share blocks but these were dismantled in response to opposition by institutional shareholders and the London Stock Exchange. The result was a regulated market in corporate control and a capital market that looked very different from its European counterparts. Thus, while acquisitions facilitated the growth of family controlled firms in the first half of the century, they also diluted their ownership and ultimately their control in the second half.

Julian Franks

London Business School

jfranks@london.edu

Colin Mayer

University of Oxford

colin.mayer@said-business-school.oxford.ac.uk

Stefano Rossi

London Business School

srossi@london.edu 
I strut around my stately life Hand in hand with lover and wife. I even own a share or two In a family firm my father grew.

Of course I have not the slightest view

On what this firm is supposed to do.

Nor have I any reason to care Since in absentia I sit in a Chair, Of a Board that yesterday I chose to hire And tomorrow I've decided that I will fire.

\section{$1 \quad$ Introduction}

The UK is a strange country. It does not have concentrated ownership; most countries do. It does not have pyramid structures; most countries do. Family ownership is of limited significance; in most countries it is extensive. There are few dual class shares; in many countries they are extensive. It has an active market in corporate control; elsewhere, it is largely non-existent.

By way of a measure of its peculiarity, Becht and Mayer (2001) report that in a majority of listed Austrian, German and Italian firms there is a single voting block of shares that commands a majority of votes in these companies. Families account for $45 \%$ of blocks in Austria, $32 \%$ in Germany and 30\% in Italy. The average size of the blocks is $26 \%$ in Austria, $27 \%$ in Germany and $20 \%$ in Italy. In the UK, on average the largest voting block will usually cast under $10 \%$ of votes, while less than $5 \%$ of blocks are attributable to families and the average size of their blocks is only 5\%. There is a stark contrast in the significance of families in corporate control between the UK and the rest of Europe.

Even by the standards of the US, the UK is odd. Dual class shares are by no means absent from the US. Powerful families established some of the largest corporations in the US and pyramids were at least at one stage widespread. The US may be odd but Britain is even more peculiar.

Why is the UK so different? Was it always so deviant? The British business history literature would seem to suggest not. Family ownership has been a dominant theme in 
British business history. Alfred Chandler developed a thesis of comparative industrial performance around differences between managerial capitalism in North America and family organizations in Europe. He argued that the UK was held back at the turn of the century by a continuing reliance on family as against professional managerial capitalism. Successes were restricted to industries in which there were modest investment requirements, most notably branded packaged goods. Companies such as Beechams, Cadbury, Colman, Reckitt and Rowntree were dominated by their owners and had little professional management. The consequences were most seriously felt in those industries that required large-scale investments - chemicals, electrical equipment and metals; these declined markedly in relation to their German and US competitors. David Landes (1965, pp 536-64) described the stereotypical image of the British family firm as being an organization founded by fanatical fathers and succeeded by squabbling siblings who "worked at play and played at work".

According to this view, at the beginning of the $20^{\text {th }}$ century, as in most other countries, powerful families dominated the British corporate sector. They may have been incompetent but at least they were there and presumably their extinction was a consequence of their incompetence. As a result, the origins of the British corporate system are quite conventional and its current anomalous status is a consequence of the normal workings of market forces.

Plausible though this story is, we argue in this paper that it is probably not an accurate and certainly not a complete description of what transpired. At the very least it does not capture the rich interaction that occurred between financial markets and companies in the UK.

There are many aspects of this that are misleading. The first is that while families were important at the beginning of the twentieth century, their significance did not in general derive from long-term large-scale ownership of British companies. By way of ownership, families were rapidly marginalized. The pattern of ownership, which we report above as characterizing corporate Britain today, emerged early in the twentieth century. 
Instead, the significance of family influence claimed by Chandler comes from a different source. While families rapidly relinquished ownership, they retained control through their positions on the boards of directors. They often held the all-important position of chairman of the board and even if they did not then their board representation was frequently disproportionate to their ownership stakes. This is quite different from the pattern observed in Continental European countries of extensive family ownership with delegated managerial control. In Britain families exerted power without responsibility whereas in most countries they had responsibility with at least limited power.

Still more interesting than the nature of ownership and control was the process by which it came about. Family ownership did not for the most part decline because families sold out. They did not typically abandon firms through company flotations or share sales. Instead, their holdings were diluted in the process of issuing shares to finance growth. In a sample of firms that we will describe below, we estimate that issues of shares associated with acquisitions, rights issues and placings accounted for almost two-thirds of the decline in directors' shareholdings over the period 1900 to 1950. A majority of this issuance arose from one particular activity of firms, namely acquisitions. More than half of the dilution (36.2\%) of the $61.6 \%$ is associated with issues of shares for acquisitions. Shares were not primarily issued to finance internal investments but rather to acquire other firms.

The changing pattern of ownership of British firms during the century was primarily a product of the immense amount of takeover activity that occurred during the $20^{\text {th }}$ century. Hannah (1976), for example, documents the three major merger waves that occurred around 1900, 1920 and 1930. Many of these mergers were consolidations of several companies, establishing the corporate groupings that dominated the rest of the century.

What is remarkable about this process of ownership dilution is that it occurred in largely unregulated equity markets with little protection to minority investors. In this paper we explore this acquisition process. We document how it went through various stages. In the first half of the twentieth century there was no market for corporate control. All mergers were the result of an agreement between the two or more boards 
of the merging companies. Often a holding company was created to buy all the shares of the combining firms, with the old boards of directors forming a new board. Mergers were the result of co-operation rather than competition between companies for a target in an auction market.

During the 1940's and 1950's there were important changes in the UK capital markets. First, following a number of scandals, minority investor protection was strengthened at the end of the 1940's. Disclosure was improved and anti-director provisions were introduced. Second, there was a sharp increase in institutional ownership. By 1960, institutions were the largest shareholder in more than a third of the companies in our sample. Third, and most significantly, a market for corporate control emerged: "for the first time it became popular for the ownership of public companies to be determined simply by stock market transactions and for control to pass thereby to parties previously unconnected with the firm" (Roberts (1992) p.183).

Charles Clore launched the first hostile takeover in 1953 for a large shoe chain called J. Sears Holdings. This bid introduced the concept of paying a significant premium for the shares of target firms. Whereas before 1950 there was little difference in cost between partial and full acquisitions, the emergence of hostile takeovers substantially increased the cost of acquiring full ownership. As a consequence, it became attractive to make partial rather than full bids for companies.

Companies responded by attempting to protect themselves and their minority shareholders against the takeover threat. We estimate that within a period of 15 years about $7.5 \%$ of listed companies had issued dual class shares with discriminatory voting rights. In others, they sought protection under the wing of a friendly parent. In particular, in the brewing industry, Whitbread provided protection through large stakes to several local brewers under what became known as 'the Whitbread umbrella'.

Partial acquisitions, dual class shares and strategic block holdings gave rise, at least temporarily, to shareholding patterns that are currently commonplace on the Continent but were previously rare in the UK. This is a particularly interesting stage in the development of the British corporation because it could at this point have switched 
into Continental European mode with dual class shares and pyramids. In Japan, similar takeovers threats in the post WW2 period prompted the erection of elaborate defences in the form of cross-shareholdings that have persisted until today. But this did not happen in Britain. Financial institutions had become steadily more influential investors in equities by the 1950s and 1960s, and with the agreement of the stock exchanges they were able to deny these firms access to the capital markets. The result was the dismantling of the protective measures until they were virtually extinguished by the 1980's. The elimination of dual class shares and pyramids in the UK was therefore due to the dominance of institutional investors. In other countries, corporations were more significant holders of corporate equity ${ }^{1}$ and derived benefits from the retention of mechanisms such as pyramids and dual class shares for sustaining control.

Instead, the more enduring response to the emergence of a market for corporate control was regulatory. The Takeover Panel was established in 1968. Its first rules included mandatory bid and equal price requirements ensuring offers be made at the same price to all shareholders once $30 \%$ of a target had been purchased. These two rules had the effect of both preventing discriminatory price offers and the build up of large share blocks.

By the beginning of the 1970's the key features of current UK corporate ownership and control were in place: substantial institutional shareholdings, a hostile takeover market and extensive minority investor protection. Together they had the effect of establishing active markets in corporate control.

In a companion paper, we have documented that dilution of family ownership has been a feature of the whole of the twentieth century, in large part due to share acquisitions. But not only was acquisition the main cause of the dilution, it was also its main effect. At the start of the century families could expect to retain control over extended periods as directors if not owners of their firms and their approval was required before changes in control through takeover could take place. By the end of the century, family board representation was not sufficient to ensure continuity of

\footnotetext{
${ }^{1}$ See, for example, Franks and Mayer (2001) for data on corporate holdings in Germany.
} 
control in the face of hostile takeovers. This had two consequences. Firstly, the feature that Chandler had noted of the dominance of management by families was less evident by the end of the century. Secondly, dilution of ownership had control as well as cash flow consequences for families. Management had therefore become more professional and families were unable to preserve the continuity of control that they enjoyed in the first half of the century.

As Davies and Hopt (2004) note, despite similarities in the structure of their capital markets and the common law nature of their legal systems, the UK and US today allocate decision rights regarding takeover offers in very different ways. In the UK they reside with the target shareholders, whereas in those state jurisdictions in the US that are sympathetic to the use of poison pills as takeover defences, most notably in Delaware, they reside with the target management. The exposure of target management to hostile takeovers in the UK is not therefore simply a product of its common law or dispersed ownership system. Politics, in the guise of the growing influence of institutional investors in the second half of the $20^{\text {th }}$ century, may have been at least as important in establishing the UK's unusually active market in corporate control.

In Section 2 we describe the data sets that we employ in this chapter. In Section 3, we record the evolution of family ownership, board representation and the rise of institutional share ownership. Section 4 describes the merger and acquisitions process in the first of the century. Section 5 looks at how a takeover market emerged in the second half of the twentieth century. Section 6 concludes the chapter and examines the implications of these developments for family control of British companies. 
We employ three data sets in this chapter. The first comprises individual firm data on the ownership and board representation of samples of firms incorporated around 1900 and 1960. There were 20 firms that were incorporated or (re-) incorporated between 1897 and 1903 and were still in existence in 2001 and 20 firms that were incorporated between 1958 and 1962 and were still in existence in 2001; we have collected data on all of these. To avoid the obvious bias that might arise from the greater longevity of the 1900 than the 1960 sample, we collected a third sample of 20 firms incorporated around 1900 that are no longer in existence today. We compare the evolution of ownership and control of the 1960 sample with both the surviving and non-surviving 1900 samples.

The data have been assembled from (i) archives of company accounts and share registers (including names and size of shareholdings) stored at Companies House in Cardiff, and at the Public Records in Kew, Richmond (Surrey) ${ }^{2}$ (ii) new issue prospectuses at the Guildhall Library in London, (iii) annual issues of the Stock Exchange Year Book which lists names of directors and the sources of any changes in issued capital, and (iv) Official Lists of trading of securities from the British Library in London. Share registers provided evidence of annual ownership changes and the annual returns to Companies House gave details of resignations of existing directors and appointments of new directors.

From these data, we collected names of directors, their shareholdings (including those of their families), the date and amounts of capital issued in acquisitions, new share issues via public and private placements, and other changes in share capital, such as capitalisations of reserves. We traced the founding family ownership from incorporation until the last family member left the board by recording shareholdings and place of residence of family members taking account of name changes across

\footnotetext{
${ }^{2}$ Since the beginning of the $20^{\text {th }}$ century, firms in the UK have been required to file information at a central depository called Companies House now situated in Cardiff, Wales. This is a remarkable and largely unique long-run source of data on firms. However, it suffers from one deficiency: Companies House retains complete records on all firms that are still in existence today but discards information on most but not all dead companies. We therefore supplemented data from Companies House with a second source of public information from the Public Records in Kew, Richmond (Surrey), which keeps some information on dead companies.
} 
generations, when for example the daughter of a founder married. We also traced shareholdings through intermediary firms. For outside shareholdings, we limited ourselves to stakes greater than $1 \%$ of ordinary capital. We used newspaper archives to document evidence of tender offers and trading in provincial Stock Exchanges, especially in the early 1900 s.

The second data set collected for this study includes information on anti-takeover defences (dual class shares, voting right restrictions and insider block holdings) for about 1800 listed firms in two LSE industry classifications, Breweries and Industrials and Commercials.

The third data set comes from Hannah's (1974a) list of takeovers over the period 1919 to 1939 and includes announcement dates of takeovers from the Financial Times newspaper, the medium of exchange, dividend changes and board turnover from the Stock Exchange Year Book, and share prices from the Daily Official List (at the Guildhall Library). Newspaper archives are used to document evidence on the hostility of takeover activity, particularly during the 1950s and early 1960 s.

\section{Ownership and Board Representation}

\subsection{Ownership}

According to Rajan and Zingales (2003), the UK has had one of the largest stock markets in the world throughout the twentieth century. Table 1 reports the number of companies listed on the London Stock Exchange (LSE), and the market value of listed securities for the period 1853 to 1939. As the Stock Exchange did not collect

aggregate statistics over this period, several other sources have had to be used. According to Killick and Thomas (1970) and Michie (1999), around 1850, provincial stock exchanges had more listed companies than the LSE - 490 as against 200. Hart and Prais (1956) record a large expansion of listed companies on the LSE over the period 1885 to 1939 though their data only refer to industrial and commercial companies. From 1963, the LSE has kept a continuous series of aggregate equity market values, including preference and dual class shares. One of the most striking 
features is the marked decline in the number of listed firms that has occurred over the past 40 years (see Table 1).

Table 2 records family shareholdings of a sample of 20 companies incorporated around 1900 and 20 incorporated around 1960 that were still in existence in 2001 (the "survivors") and a sample of 20 companies incorporated around 1900 that died during the century ("non-survivors"). It documents the number of companies where the founding family's shareholding passes a particular threshold of $25 \%, 50 \%$ and $75 \%$ of equity. Franks, Mayer and Rossi (2004) report that insider ownership declined rapidly and at similar rates in the first and second half of the centuries. Rates of ownership dispersion were similar in samples of companies incorporated in 1900 and 1960. Table 2 confirms that family ownership was rapidly diluted throughout the century. By 1940, forty years after incorporation, the number of firms in which families owned more than $25 \%$ of shares had declined from 13 to 4 amongst the survivors. Family ownership was initially even less pronounced amongst the nonsurvivors ( 9 out of 20 companies passed the $25 \%$ threshold) but pro-rata to the number of survivors it then declined less rapidly to 4 out of 12 survivors in 1940.

Table 2 shows that this dilution of family ownership was even more noticeable in the 1960 than in the 1900 sample. For example, forty years after incorporation, there was no company in the 1960 sample in which family ownership passed the $25 \%$ threshold. Family ownership therefore diminished rapidly throughout the century but much more so in the second half of the century.

Table 3 documents how financial institutions emerged to take the place of families as dominant owners of corporate Britain around the middle of the twentieth century. It reports the number of cases where a financial institution was the largest shareholder of our sample of firms. Forty years after incorporation, there were 4 cases in the 1900 survivor sample where a financial institution was the largest shareholder compared with 13 in 1990 for the 1960 sample. The average size of institutional stakes was also larger in the second half of the century. The average stake of the 4 financial institutions that were the largest shareholders in the 1900 sample was $5.9 \%$ in 1940 , compared with an average stake of $16.2 \%$ in the 13 companies in the 1960 sample in 
2000. Thus, in the first half of the century institutional shareholdings were largely absent, and where they were present they were quite small. In contrast, in the second half of the century, there were a larger number of stakes held by institutions and they were much more significant in size.

In summary, family ownership declined rapidly in the first half of the $20^{\text {th }}$ century and institutions emerged to take the place of families from the middle of the century

\subsection{Board representation}

Table 4 shows that family representation on boards persisted for much longer than their ownership. It documents the profile of board representation for the two samples of firms at ten yearly intervals. Over forty years from 1900 to 1940, the percentage of board seats held by outside (non-family) shareholders in the sample of survivor firms (panel A1) increased from $46 \%$ in 1900 to $64 \%$ in 1940 . The proportion of firms in which families occupied the position of CEO of the board declined from 80\% (i.e. 16 out of 20 ) to $50 \%$ (i.e. 10 out of 20 ). As Table 2 recorded, the proportion of survivor firms in which families held more than $25 \%$ of shares declined much more rapidly by $45 \%$ from $65 \%$ (i.e. 13 out of 20 ) in 1900 to $20 \%$ (i.e. 4 out of 20 ) in 1940 . Family representation on the boards did not therefore decline as rapidly as their ownership.

Table 5 provides a summary measure of this. It reports separation of family ownership and control as measured by the difference between family representation on the boards of firms and family ownership of shares. A positive number means that family board representation is disproportionate to their ownership. Table 5 shows that at the beginning of the century, family ownership was in excess of their board representation but by 1940 it had become disproportionately high.

Panel A2 of Table 4 reports lower family board representation amongst the 1900 nonsurvivors than the survivors. Family board representation was only 32\% in 1900 in comparison with 55\% amongst the survivors and it declined to $7 \%$ in 1940 . There was therefore less family ownership and less family board representation amongst the non-survivors than the survivors in 1900 and families failed to retain board positions amongst non-survivors to the degree that they did in survivors. Table 5 confirms that 
family board representation did not increase to the same extent relative to ownership amongst non-survivors as amongst survivors. So families retained neither ownership nor board positions amongst non-survivors. Whether the decline of families on the boards as well as in the ownership of non-survivors was a cause or a consequence of their demise is not a question to which we attempt to provide an answer here. All we do is to note that the difference in family ownership and board representation amongst surviving and non-surviving firms may be an interesting approach to evaluating the contribution of families to corporate performance.

In the second half of the century, family representation on boards declined more rapidly. Forty years after incorporation, a family member was chairman/CEO in three companies in the 1960 sample in comparison with 10 in the 1900 survivors. Likewise, the proportion of seats on the boards occupied by families declined to $16 \%$ forty years after incorporation in the 1960 sample in comparison with $36 \%$ in the 1900 sample. Thus, family representation on boards as well as ownership declined more rapidly in the second than in the first half of the century.

Table 4 shows that relative to their ownership stakes, family representation on boards moved in a very similar way in the 1960 to the 1900 survivors, starting from slightly more ownership than board representation in 1960 and ending with markedly more board representation than ownership 40 years after incorporation in 2000. Thus, families did not match the very rapid decline in their ownership in the second half of the century with their share of seats on boards of firms.

In summary, dilution of family ownership occurred rapidly throughout the twentieth century. As the next section describes, this was primarily due to growth through acquisition. However, in the first half of the century families were able to retain control in surviving firms through representation on the boards of firms. In the second half, board control as well ownership was rapidly extinguished. A new form of ownership, institutions, emerged in the middle of the century to replace families, and, as we document in Section 5, a new form of corporate control, the hostile takeover, appeared to replace that exerted by families.

\section{$4 \quad$ Mergers and acquisitions in the first half of the century}


Franks, Mayer and Rossi (2004) argue that the main cause of dispersion of ownership during the twentieth century was equity issuance. In particular, their sample of firms grew rapidly through acquisition and in the process issued equity to outside shareholders thereby diluting insiders' shareholdings. Franks, Mayer and Rossi report that insider holdings were diluted over the period 1900 to 1950 at an average rate of $12.6 \%$ per annum. Of this, none was attributable to IPOs, $4.6 \%$ to rights issues, $20.8 \%$ to placings and $36.2 \%$ to mergers and acquisitions. ${ }^{3}$

During the first half of the century mergers and acquisitions were usually made by the bidder approaching the directors and agreeing to purchase their shares. "An approach through the directors, followed by controlled stock transfers on the recommendations of the directors (rather than contested takeover raids) remained the norm in these years". (Hannah (1974b), p. 68). A price was negotiated and management wrote to the shareholders stating that "the offer has been unanimously accepted by the Directors of your company for the whole of their individual shares, and they have no

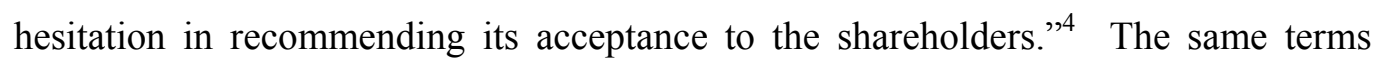
were offered to outside shareholders as the directors.

As Hannah (1974b) has noted, "the loyalty of shareholders to directors was strong, and the directors of other companies had a natural aversion to challenging it. Even if a direct bid were to be made, the directors of the victim firm remained in a strong position relative to their own shareholders. In practice the shareholders would recognize the superiority of the directors' information and tend to take their advice on the true value of the company in relation to the bid price." (p. 70-71) "Directors felt a responsibility to recommend offers to their shareholders when the bid price was pitched reasonably." (p. 68-69). It is therefore unsurprising that there was a complete absence of hostile takeover bids in the first half of the century.

\footnotetext{
${ }^{3}$ In the first half of the century shares were often traded without a prospectus. Shares would simply be issued and sold directly by the company to subscribers or be sold through advertisements in the press. The IPO event was much more formal after 1948 when prospectuses were compulsory and their content strictly regulated prior to trading on recognized stock exchanges such as the LSE.

${ }^{4}$ Quote from Financial Times, Monday 19 January 1920.
} 
The continuing presence of families on boards, in particular in the position of chairman, even in the absence of ownership, may have been important in upholding reputations. So too were titled directors. Florence (1953) reports that there were 654 English peers as active members of city firms in 1932. Titled directors were particularly common in the largest companies. "At a rough estimate almost half the titled directors inherited their title or acquired it by prowess in the fighting services or sport and not in business" (Florence (1953), p 245). "One well-known insurance company in 1937 had among sixteen directors, three knights, one baron, one marquis, one earl and two dukes" (p 245). Likewise, May (1939) reports that of 654 British peers, 189 of them were directors of companies and held 562 directorates between them. "Sometimes a man with a "good name", knowing nothing about the business and even without residence in the country, is set up as chairman with the principal duty of reading the annual speech, which has been written out for him, to the shareholders" (May (1939), p. 145). As Lord Justice Scrutton said in the Court of Appeal in the judgement on Combined Pulp and Paper Mills Ltd 1932 "the company promoter wants a man whose name will appeal to the public and who does not know too much about the business. The name will attract capital - the company promoter will do the rest" (pp. 35-36 of the transcript).

In Tables 6 and 7 we examine the workings of the acquisitions market in the first half of the century. We undertook a series of tests on bid premia, changes in boards, dividend responses of targets similar to those that are now routinely performed on recent acquisitions in the UK and US. We report data on $41 \mathrm{M} \& A \mathrm{~s}$ in the UK over the period 1919 to 1939 . This is the entire population of M\&As that met three criteria: the market value of target assets exceeded £I million pounds, the targets were listed on the LSE and they were classified by the LSE as being in one of three industries - breweries and distilleries, industrial and commercial, or iron, coal and steel.

Table 6 shows the proportion of target directors who were retained on the board after the merger, the number of cases in which the chairman was removed and the change in dividends around the announcement of the mergers. On average, two-thirds of the target directors remained on the target's board after the acquisition. In 14 of 41 cases (approximately one-third of the total), the chairman was removed. In comparison, in 
a study of 35 successful hostile takeovers in 1985 and 1986, Franks and Mayer (1996) report that $90 \%$ of directors were replaced within two years of the bid being consummated. The equivalent figure for 35 accepted bids was $50 \%$. Board turnover was appreciably lower in the first half of the century in comparison with both accepted and hostile bids in the second. ${ }^{5}$

Table 6 also shows very little change in dividends in the year of the bid compared to the previous year in the 1919 to 1939 sample. In comparison, Franks and Mayer (1996) report that dividends were increased in a substantial proportion of both hostile and accepted takeovers in 1985 and 1986. They were increased in 76\% of targets of successful hostile takeovers in the year before the bid and in $73 \%$ of targets two years before the bid.

But it is in relation to bid premia that the differences are most pronounced. Panel A of table 7 records that in the sample of 40 targets target shareholders received bid premia of $-0.9 \%$ during the month of the bid (i.e. 'month 0 '), calculated on an equal weighted basis. These bid premia are raw equity returns with no adjustment for market movements or risk. Bid premia for months -4 to +1 on the same basis were 4.9\%. Bid premia were therefore little different from zero. In contrast, Franks and Mayer (1996) report bid premia of between 20 and 30\% for hostile and agreed bids during 1985 and 1986 in the UK.

The picture that emerges is one of cooperative consolidations between merging firms in the first half of the century. The support of management was required for approval by shareholders. Bid premia were low, the medium of exchange usually involved share exchanges, management was frequently kept on the target board and dividend changes were modest. Since acquisitions frequently involved share exchanges, acquiring firms avoided the devaluation of their currency that dual class shares would have entailed. The absence of dual class shares in the first half of the century may therefore have been intimately linked to the importance of takeovers and their form of financing.

\footnotetext{
${ }^{5}$ This might indicate greater private benefits accruing to target directors in the early part of the century.
} 
This picture of cooperation and little competition was dramatically altered in the 1950s, as we will describe in Section 6.

\section{Three Case Studies}

This section describes three cases that illustrate the way in which three prominent British firms expanded during the $18^{\text {th }}, 19^{\text {th }}$ and $20^{\text {th }}$ centuries, the contribution of acquisitions to their growth, the changing nature of family ownership and board representation, and the contribution of incorporation and mergers to that process.

\subsection{GKN}

Dowlais Iron Company was set up in 1759 in the village of Dowlais near Merthyr Tydfil in South Wales. John Guest was appointed as manager of Dowlais in 1767, and his grandson became the company's sole owner in 1851. The Dowlais Iron Company was at this stage the largest iron works in the world, operating 18 blast furnaces and employing more than 7,300 people. The business was the first licensee of the Bessemer process, constructing the world's most powerful rolling mill in 1857, and producing its first Bessemer steel in 1865.

The Keen family established the Patent Nut and Bolt Company in 1856 in Smethwick, England. In July 1900, Guest, Keen and Company Limited was incorporated in Birmingham with the purpose of taking over the Dowlais Iron Company and the Patent Nut and Bolt Co., Ltd. The shareholders of the two companies received 250,000 ordinary shares. At the same time, 400,000 ordinary shares were issued via public subscription and the company was floated with 546 ordinary shareholders and more than 2000 preference shareholders. Both classes of shares were traded on the London and Birmingham Stock Exchanges. There was no evidence of the company being dispersed before 1900: the company history suggests that both Dowlais Iron Co. and the Patent Nut and Bolt were $100 \%$ owned by directors and their families. Evidence for this comes from a comparison of directors' holdings with the shareholdings of the two companies before the merger. Since directors' holdings after the flotation were $33.6 \%$ of the ordinary shares, and the newly issued shares 
were 400,000 , compared with a pre-issue total of 250,000 we can compute a lower bound of directors' ownership pre-issue of $87.3 \%$.

In 1902 the company acquired Nettlefold and Company, one of the world's leading manufacturers of screws and fasteners set up in Smethwick in 1854, by issuing 315,000 new ordinary shares. The new company name was then called Guest, Keen, and Nettlefolds Limited, and Mr Edward Nettlefold joined the board. By 1910, the directors held $26.4 \%$ of issued ordinary shares. In 1920, shares in Guest, Keen and Nettlefolds Ltd. (GKN) were quoted at Birmingham, Bristol, Cardiff, Edinburgh, Glasgow, Liverpool, Manchester and Sheffield, while the prices of the transactions were marked (i.e. reported) on the official list of the London Stock Exchange.

A crucial decade in the evolution of ownership and control of GKN was then about to begin. First, the company acquired John Lysaght Limited of Bristol (also quoted in Bristol and London) in one of the largest tender offers of the decade. ${ }^{6}$ GKN then undertook two other major tender offers in November 1923, acquiring D Davis and Sons and Consolidated Cambrian of Cardiff.

As a consequence of these acquisitions there was a huge increase in the number of shareholders: GKN had about 1,000 shareholders before 1920, and more than 20,000 in 1924. At this stage, GKN was one of the largest manufacturing businesses in the world, involved in every stage of manufacturing from coal and ore extraction to iron and steel making and finally to finished products including the nuts, bolts, screws, and fasteners for which it was renowned during this period.

GKN formally listed on the London Stock Exchange on June 14, 1946. By then the directors owned a negligible stake and the largest shareholder of the period was the Royal Bank of Scotland with $2.37 \%$ of issued ordinary shares. In the second half of the century, Prudential Assurance, Norwich Union Life Insurance, Schroder Investment Management, and Scottish Widows Investment Management among

\footnotetext{
${ }^{6}$ Details of the deal are as follows: in January 1920, GKN issued 1,989,919 new ordinary shares and 2,652,331 preference shares. Ordinary shareholders of John Lysaght Ltd were offered 4 new $2^{\text {nd }}$ preference and 3 new ordinary shares in GKN for every 3 ordinary shares held.
} 
others alternated as the largest shareholders with stakes varying from $3 \%$ to $5.25 \%$ of issued equity capital.

The picture that emerges from GKN is of a firm whose shares were initially traded on local provincial exchanges, that expanded rapidly through acquisitions, broadened its shareholder base both numerically and geographically in the process, and that by the beginning of the second half of the twentieth century was widely held primarily by institutional shareholders.

\subsection{Case Study of Schweppes}

In 1783, 43-year-old German born Jean Jacob Schweppe invented an efficient system for the manufacture of mineral water. In 1790, he entered a partnership to expand the business and established a factory in London, UK. Around 1800 he changed his and the business name to Schweppes, while continuing to expand on a national scale. By 1831, J. Schweppes \& Co. becomes the Supplier of Soda Water to the Royal Household. In 1834, John Kemp-Welch and William Evill bought J. Schweppes \& Co., and extended the product range to include flavoured soda drinks such as lemonade. The following year the firm was awarded the Royal warrant by Queen Victoria, and in 1851 it won the contract to supply "Temperance" beverages at the Great Exhibition in the UK. By 1870, the firm's product range included Tonic Water and Ginger Ale. The former rapidly became popular with the British in India, as it contained quinine, which was used as a preventive measure against malaria. In 1877 the firm opened its first factory in Sydney, Australia, and seven years later a factory in Brooklyn, NY.

The sudden death of John Kemp-Welch in 1885 precipitated the formation of Schweppes as a limited company in the following year. Although no direct evidence exists on the ownership structure at this stage, it would appear that the company was $100 \%$ owned by the directors until its public flotation in London on March 6, 1897. After flotation the directors and their families held collectively $27.2 \%$ of the 300,000 ordinary shares. The new company, Schweppes plc, was incorporated to acquire the business of J. Schweppe and Co. established in 1783, and a total of £1,250,000 new capital (of which $£ 300,000$ was perpetual debenture stock issued to the directors, and 
$£ 950,000$ was a public subscription, in the form of 300,000 ordinary shares, 300,000 preference shares and 350,000 deferred shares).

The public flotation was extremely successful and over-subscribed. At the end of 1897, there were more than 1650 ordinary shareholders and 750 preference shareholders. There was evidence of the company's shares being traded in Manchester.

In 1919 the Kemp-Welch family relinquished the chairmanship (although two members remained on the board until the early 1940s), and under the new chairman, Sir Ivor Phillips, the company started a new period of expansion. Overseas development was conducted through a newly formed fully owned subsidiary, Schweppes (Colonial and Foreign) Ltd. The strategy was to manufacture locally in the overseas countries, in order to reduce the group's reliance on exports. At the end of Sir Phillips chairmanship in 1940, the company had more than 2,700 ordinary shareholders, and it was formally listed on the London Stock Exchange in December $19,1942$.

During the 1950s there were several major acquisitions paid in shares: L. Rose and Co. acquired in 1957 with 1,544,400 new ordinary shares, and Chivers \& Sons, W.P. Hartley, and W. Moorhouse all acquired in 1959 with together 4,000,000 new ordinary shares. In 1969, Schweppes PLC merged with the Cadbury Group to form Cadbury-Schweppes.

\subsection{Case Study of Cadbury}

In 1794, Richard Cadbury a prominent Quaker moved from the West Country in Britain to Birmingham. Thirty years later his son John opened a shop at 93 Bull Street, then a fashionable part of Birmingham, to sell tea, coffee, hops, mustard, and a new sideline - cocoa and drinking chocolate, which John prepared himself using a mortar and a pestle.

In 1847 John Cadbury took his brother Benjamin into partnership in 1847, changing the name of the business to Cadbury Brothers of Birmingham, and renting a new 
factory in Bridge Street in the centre of Birmingham. Thanks to a reduction in tax on imported cocoa beans, the business expanded and received the first of a series of Royal Warrants of appointment by Queen Victoria.

The Cadbury Brothers moved their manufacturing operations to Bournville, UK, and established the Bournville factory and village, which became an important addition to the UK industrial landscape. By the time that Cadbury Brothers was incorporated as a limited company in June 16 1899, the Bournville factory had 2,600 employees. At that stage, Richard and George Cadbury, the sons of the late John Cadbury, owned $100 \%$ of the ordinary shares.

1919 was a crucial year in the company history when Cadbury Brothers merged with JS Fry \& sons of Bristol, whose product range (e.g. Turkish Delight) complemented Cadbury's chocolates. After the merger, the new company was registered as British Cocoa \& Chocolate in May 19, 1919, with a capital of $£ 2,500,000$. The two families shared both board seats and company ownership, with the Fry's holding 4 seats on the board as well as the chairmanship and $45.44 \%$ of ordinary shares, and the Cadburys holding the rest (6 seats on the board, and $54.56 \%$ of ordinary shares). Another former director of Fry also sat on the board.

As the companies operations expanded, and factories opened around the world, the Fry family board representation declined, while Cadbury's increased. Shortly before the merger with Schweppes plc in 1969, the Cadbury family held the chairmanship and 7 of the 13 seats of the board of directors, while only one Fry remained on the board. The Cadbury family held slightly more than 50 percent of the ordinary shares, while the Fry family held just over $10 \%$. The rest was dispersed among more than 200 ordinary shareholders. There was evidence of trade on both London and Birmingham Stock Exchanges of ordinary and preference shares before the merger with Schweppes in 1969.

These three case studies illustrate the speed with which ownership was dispersed and how much of the dilution of the original family's ownership was due to acquisitions for share exchanges. They also show how one of the founding families came to 
dominate the merged entity even where the merger was apparently between equals. This dominance persisted as the ownership of the founding family dwindled.

\section{Takeovers in the second half of the century}

In the Spring of 1953, Charles Clore, a self-made millionaire from business and property ventures, launched a bid for J. Sears \& Co., the parent company of a shoe shop chain-store, Freeman, Hardy and Willis. Instead of following the conventional approach of negotiating with target management, Clore mailed offer documents direct to Sears' shareholders over the heads of management. "The Sears directors, who were taken entirely unawares, retaliated by announcing the tripling of the dividend. Shareholders were astonished by this sudden largesse, which was perceived as a desperate and irresponsible act on the part of the management. Faith in the incumbent board being thoroughly undermined, there was a rush to sell to Clore, who quickly acquired control of the company. 'We never thought anything like this would happen to us', were the Parthian words of the outgoing Sears' chairman." (Roberts (1992), p. 186).

The unconventional nature of the approach was reflected in exceptional financial features of the bid. In contrast to the observation made above that dividends did not in general change around acquisitions, the Sears' directors responded to the bid by tripling the value of their dividend. While the average value of bid premia had historically been around zero, the bid premium for Sears was $90 \%$ in the month of the bid and $122 \%$ in the five months from month -4 to +1 .

As Table 7 shows, there were then several bids that recorded bid premia that were very large by previous standards. In the case of the bid by Land Securities Investment Trust in autumn 1953 for the Savoy Hotel Co., owners of the Savoy, Claridge's and Simpson's in the Strand, the bid premium was $19 \%$ in the month of the bid and $87 \%$ in the five months around the bid. In the bid for British Aluminium by Reynolds Metals of Virginia in 1958 , the month zero bid premium was $17 \%$ and the five months bid premium was $17 \%$. 
It is not entirely clear why the takeover market emerged at this juncture in Britain. Alfred Chandler associates the emergence of a market for corporate control in the US with the rise in institutional shareholding (Chandler (1990)). But, as Table 3 shows, in the UK the market for corporate control predated the accumulation of most institutional shareholdings. A more plausible explanation is that the tighter financial disclosures required of company accounts by the 1948 Companies Act provided the basis on which corporate predators could for the first time make reasonably accurate estimates of asset values and earnings, and thus launch bids without the co-operation of the target (Hannah (1974b)). In Charles Clore's takeover of Sears, Roberts (1992) reports that "Clore launched his attack on being informed by a partner in the estates agent Healey \& Baker that Sears' balance sheet under-estimated the real estate value of the firm’s 900 high street stores by $£ 10$ million” (page 186).

The response of the corporate sector was to seek protection against the rapidly emerging takeover market. It initially received a sympathetic ear from the government and the Bank of England, which were concerned about the impact of hostile acquisitions on the corporate sector and the government's policy of dividend restraint (Roberts (1992)). All levels of government were involved including in the case of the bid for the Savoy, the Prime Minister, Winston Churchill, who was worried about the possible impact of the bid on his favourite dining club at the Savoy. But while it found this form of buccaneering capitalism distasteful and ungentlemanly, the government felt impotent to do much about it and in any event, by the time of the next merger wave at the end of the 1950's, it had come round to the view that "Mr Clore appears to have improved the retail shoe trade of the country".

Unable to gain protection from the government, the corporate sector began to erect its own defences. Table 8 reports incidence of anti-takeover measures in three years: 1950, 1965 and 1975. In the case of 1965 and 1975 the table also shows changes (adoptions of anti-takeover defences in existing companies, emergence of new companies with anti-takeover defences and abandonment by existing companies) from 1950 and 1965 respectively. Anti-takeover measures are said to exist if any of the following are present: dual class shares, voting restrictions or share blocks by insiders in excess of $50 \%$. Statistics are reported for three London Stock Exchange sector 
classifications: Commercial and Industrial, Breweries and Distilleries, and Iron, Coal and Steel, which totals more than 2000 companies.

Table 8 reports that the number of companies with anti-takeover measures increased from 73 in 1950 to 249 in 1965. This represents an increase in incidence of antitakeover measures from $3.7 \%$ of the sample to $11.1 \%$ between 1950 and 1965 . There were 100 new adoptions by companies that were already in existence in 1950 and 92 new companies were formed with anti-takeover defences. ${ }^{7}$ The incidence of takeover defences therefore increased substantially during the 1950's and 1960's. ${ }^{8}$

A further form of takeover defence that emerged was to seek protection under the wing of a friendly company. The brewing industry was particularly fragmented with a large number of small local brewers. Whitbread took share stakes in several of these as a way of providing protection against hostile bidders.

For a brief period during the 1950's and 1960's, the landscape of corporate Britain began to resemble that of Continental Europe. There was an unregulated takeover market with the potential for acquiring control through purchases of partial share stakes and discriminatory offers. Companies responded by introducing dual class shares and voting right restrictions and pyramid structures emerged as companies sought protection under the wing of others.

But these takeover defences met with stiff opposition from an influential quarter - the institutional investors and the London Stock Exchange. They were concerned about the interference with the takeover process, the ability of management to entrench itself behind takeover defences and the withdrawal of their voting rights. Under pressure from the institutions, the Stock Exchange made it known that it disapproved of the use of dual class shares and would not permit their use in new equity issues.

The intervention of the institutions and the Stock Exchange proved decisive and during the 1970's and 1980's companies steadily withdrew dual class shares. Panel C

\footnotetext{
7 There is a residual of 16 companies that were delisted.

8 The companies with anti-takeover measures were non-acquisitive companies and did not therefore expect to use their own shares to purchase other companies.
} 
of Table 8 reports that by 1975, the proportion of listed companies with dual class shares in the three sectors had declined from $11.1 \%$ to $7.1 \%$. The number of companies in the Commercial and Industrial Sector that dropped dual class shares between 1965 and 1975 was well in excess of those that adopted them. By the late 1980s there were only a handful of companies with dual class shares left among listed companies in the U.K.

Meanwhile, under prompting from the Bank of England, in 1959 the City established a working party to produce a code of conduct for takeovers. This initially yielded a series of ineffectual recommendations but, in the face of several prominent takeover scandals ${ }^{9}$ and under the looming threat of legislation, in 1967 it produced the City Code on Take-overs and Mergers and created the Panel on Take-overs and Mergers to enforce it. ${ }^{10}$ This in due course established the principle of equal treatment of all shareholders, the requirement of acquiring firms to disclose their shareholdings and reveal their intentions, and the obligation to make offers for all shares at highest prices once $30 \%$ of the target firm's shares had been acquired. In other words, it recreated by self-regulation the equal price treatment that had prevailed by convention without regulation in the first half of the century before hostile takeovers.

What is striking about these developments is the fact that the political process was not at the end of the day guided by the interests of the corporate sector which sought to limit hostile bids and to erect takeover defences but by those of the financial institutions. It was the institutions that prevented firms from implementing dual class shares and the institutions that drew up the rules by which takeovers were subsequently conducted. It was therefore the financial sector that prevented the UK from drifting into a Continental style corporate structure with dual class shares, pyramids and limitations on takeovers and set the ground rules by which an active market in corporate control could develop. Through the takeover code and panel, the financial sector also prevented the corporate sector from erecting the takeover defences, in particular poison pills, that became commonplace in the US. The distinct nature of the UK corporate sector is therefore in part a consequence of the dominance

${ }^{9}$ One example of this was the Jasper Affair in 1959, involving take-over malpractice and the misuse of building society funds. 
of equity institutions that placed shareholder returns above the private interests of either corporate shareholders or management.

\section{Conclusions}

This paper has documented the rapid erosion of family ownership of UK corporations during the $20^{\text {th }}$ century. The dispersed ownership which characterizes the UK corporate system today emerged early in the $20^{\text {th }}$ century. The UK did not start off life in the $20^{\text {th }}$ century like Germany or Italy today. In terms of ownership concentration and the involvement of families, it looked more like the UK today than Germany or Italy.

The observations on the dominance of families in the running of firms are a reflection of their board representation rather than their ownership. Board participation by families became disproportionate to their ownership stakes. There were good reasons for being concerned about this development. The divergence between ownership and control undermined the efficient running of corporations, as documented by Chandler.

But what was remarkable about this was the process by which it came about. The decline in family ownership was not for the most part a consequence of families selling out but a result of equity issues. These equity issues were not primarily used to finance internal growth (there was rather little use of equity for this purpose in the first half of the $20^{\text {th }}$ century) but to acquire other companies. Equity financed acquisitions accounted for a high proportion of the dilution of family holdings.

What is equally striking is the fact that these substantial equity issues took place against the background of informal, largely unregulated stock markets. Nevertheless, shareholders trusted directors to uphold principles of equal price treatment for all. There was little evidence of the partial share offers and price discrimination that characterizes the takeover market in many countries today.

\footnotetext{
${ }^{10}$ The power of the Panel to sanction firms that do not comply with the Code has proved to be highly effective.
} 
Why directors abided by this and were not tempted to accept cheaper partial offers at the expense of minority investors is not entirely clear. But one clue comes from the significance of acquisitions and equity issuance to the growth of corporations. Large British companies were particularly reliant on the stock market to fund growth. This may reflect the absence of a local banking system of a type that exists in many other countries and through which companies in those countries are able to establish close relations and borrow on an ongoing basis. To be able to access the stock market, companies in the UK had to sustain the trust of their shareholders, which in part revolved around ensuring that they were equally treated in new share issues. Discriminatory offers might reduce the costs of particular acquisitions but these were more than offset by the higher cost of using equity in subsequent acquisitions. Regulation was not therefore required since it was in the self-interest of directors to ensure the fair treatment of their shareholders.

The non-discriminatory treatment of shareholders in takeovers also goes someway towards explaining the absence of pyramids in the UK. Acquirors were not able to purchase the partial share stakes in companies that would have allowed them to create pyramids. Target firms were absorbed into the merged company and essentially disappeared as separate listed entities.

However, this collaborative arrangement broke down in the middle of the century in the face of a hostile takeover market. Target directors were no longer in a position to enforce equal price rules since acquirors could go behind their back and appeal directly to controlling shareholders. Directors initially tried to protect themselves and their minority investors by erecting takeover defences. For a brief period, the UK took on the appearance of Continental Europe with dual class shares, pyramids and discriminatory price acquisitions. But the takeover defences incurred the wrath of the institutions, which mounted a successful attack on them through the Stock Exchange and succeeded in devising the rules by which takeovers were to be conducted.

Once again the development of the UK corporate sector was determined by the interests of shareholders to a degree that probably did not occur in most other countries. At an optimistic level, the reason for the oddity of the UK noted at the start is the well-developed and efficient nature of its stock market and the dominance of 
financial institutions that eschewed the private benefits of Continental Europe. Equally plausibly, it is a consequence of its centralized banking system and the unusual reliance of its corporate sector on the stock market during the $20^{\text {th }}$ century. 
Table 1 - The number of companies and market capitalization of companies listed on the London Stock Exchange

This table reports London Stock Exchange statistics on number of listed companies and market capitalization from various sources. Panel A reports various sources pre-1950, and Panel B reports London Stock Exchange data from 1963 to 2000.

Panel A - Various sources, pre-1950

\begin{tabular}{|c|c|c|c|}
\hline Date & $\begin{array}{c}\text { No. listed } \\
\text { companies, LSE }\end{array}$ & No. listed companies, Provincial & Source \\
\hline 1847 & & $490^{2}$ & Killick and Thomas, 1970 \\
\hline 1853 & 200 & & Michie \\
\hline 1913 & 1,700 & & Rajan \& Zingales, 2003 \\
\hline 1885 & $70^{1}$ & & Hart \& Prais, 1956 \\
\hline 1907 & $571^{1}$ & & Hart \& Prais, 1956 \\
\hline 1939 & $1,712^{1}$ & & Hart \& Prais, 1956 \\
\hline
\end{tabular}

Panel B - London Stock Exchange data from 1963

\begin{tabular}{|c|c|c|c|c|c|c|c|}
\hline & \multicolumn{5}{|c|}{ UK } & \multicolumn{2}{|c|}{ International } \\
\hline Date & $\begin{array}{c}\text { No. of } \\
\text { companies }\end{array}$ & $\begin{array}{c}\text { No. of equity } \\
\text { securities. }\end{array}$ & $\begin{array}{c}\text { Market value } \\
(£ / M)\end{array}$ & $\begin{array}{c}\text { GDP current } \\
\text { prices }\end{array}$ & $\begin{array}{c}\text { Market } \\
\text { development } \\
\text { (GDP/MV) }\end{array}$ & No. of companies & Market value $(£ / M)$ \\
\hline 1963 & 4,409 & 4,064 & 32,204 & & & & • \\
\hline 1970 & 3,418 & 3,197 & 37,793 & 44,200 & 0.86 & 387 & 57,135 \\
\hline 1980 & 2,747 & 2,283 & 86,720 & 201,000 & 0.43 & 394 & 183,846 \\
\hline 1990 & 2,006 & 2,081 & 450,544 & 479,000 & 0.94 & 553 & $1,124,131$ \\
\hline 12000 & 1,904 & 2,272 & $1,796,811$ & & & 501 & $3,525,701$ \\
\hline
\end{tabular}

Source: London Stock Exchange 


\section{Table 2 - Family shareholdings and ownership thresholds}

This table reports the number of companies in our sample where the founding family owns more than $25 \%, 50 \%$, and $75 \%$ of issued ordinary share capital, respectively. Panel A refers to the 1900 sample, and reports results separately for survivors and non-survivors. Panel B refers to the 1960 sample.

Panel A: Number of companies where founding family shareholdings exceed $25 \%, 50 \%$, and $75 \%$ of issued ordinary share capital for selected years, 1900 sample

\begin{tabular}{cccccccccc}
\hline \multicolumn{9}{c}{ Survivors } & \multicolumn{7}{c}{ Non Survivors } \\
\hline 1900 & 13 & 9 & 8 & 20 & 9 & 8 & 6 & 20 & 40 \\
1910 & 10 & 7 & 7 & 20 & 9 & 8 & 5 & 20 & 40 \\
1920 & 11 & 8 & 7 & 20 & 8 & 6 & 4 & 17 & 37 \\
1930 & 7 & 4 & 3 & 20 & 8 & 4 & 3 & 16 & 36 \\
1940 & 4 & 3 & 3 & 20 & 4 & 4 & 3 & 12 & 32 \\
1950 & 3 & 3 & 2 & 20 & 4 & 3 & 3 & 10 & 30 \\
1960 & 2 & 1 & 1 & 20 & 3 & 2 & 1 & 4 & 24 \\
1970 & 0 & 0 & 0 & 20 & 2 & 1 & 1 & 3 & 23 \\
1980 & 0 & 0 & 0 & 20 & 1 & 1 & 1 & 2 & 22 \\
1990 & 0 & 0 & 0 & 20 & 0 & 0 & 0 & 1 & 21 \\
2000 & 0 & 0 & 0 & 20 & 0 & 0 & 0 & 0 & 20 \\
\hline \hline
\end{tabular}

Panel B: Number of companies where founding family shareholdings exceeds $25 \%, 50 \%$, and $75 \%$ of issued ordinary share capital for selected years, 1960 sample

\begin{tabular}{rrrrc}
\hline \hline & $25 \%$ & \multicolumn{1}{c}{$50 \%$} & $75 \%$ & N. Obs. \\
\hline 1960 & 16 & 15 & 7 & 20 \\
1970 & 8 & 5 & 3 & 20 \\
1980 & 7 & 2 & 1 & 20 \\
1990 & 1 & 1 & 0 & 20 \\
2000 & 0 & 0 & 0 & 20 \\
\hline \hline
\end{tabular}

Source: Own calculations 


\section{Table 3 - Is the largest shareholder an institution?}

This table reports the number of companies where the largest shareholder is an institution, along with the average size of these largest block holdings. Panel A refers to the 1900 sample, and reports results separately for survivors and non-survivors. Panel B refers to the 1960 sample.

Panel A: Number of companies where the largest shareholder is an institution and block size for selected years, 1900 sample

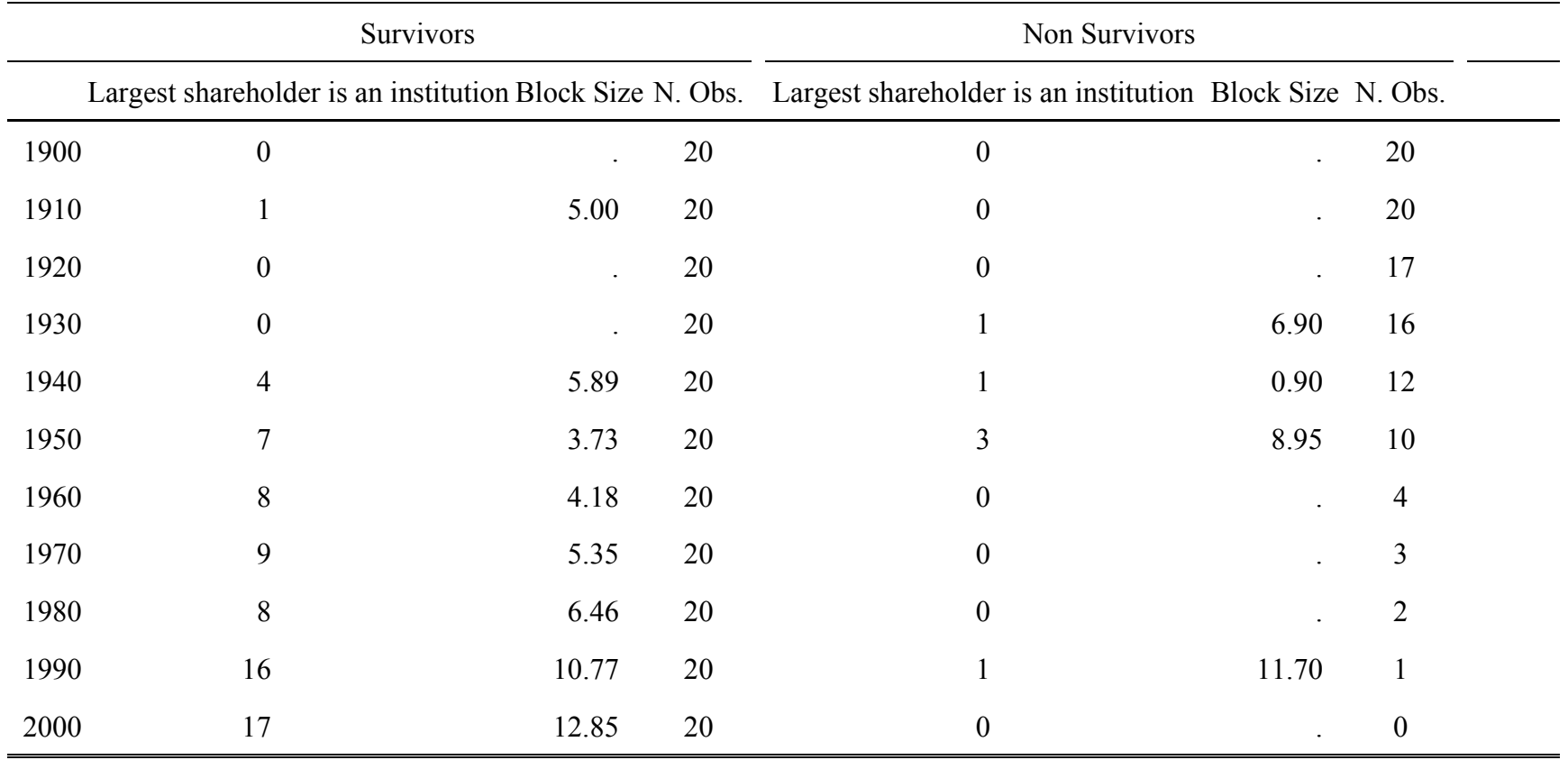

Panel B: Number of companies where the largest shareholder is an institution and block size for selected years, 1960 sample

\begin{tabular}{cccc}
\hline & Largest shareholder is an institution & Block Size & N. Obs. \\
\hline 1960 & 0 & $\cdot$ & 20 \\
1970 & 4 & 4.88 & 20 \\
1980 & 5 & 16.27 & 20 \\
1990 & 10 & 15.39 & 20 \\
2000 & 13 & 16.20 & 20 \\
\hline \hline
\end{tabular}

Source: Own calculations 


\section{Table 4- Board composition}

This table reports board size and the percentage of board members that do not come from the founding family. Panels A1 and A2 refer to the 1900 sample for survivors and non-survivors respectively. Panel B refers to the 1960 sample.

Panel A1: Board composition for selected years, 1900 sample, survivors

\begin{tabular}{lcccccc}
\hline \hline & Board size & & Family CEO & Board members outside founding family (\%) & N. Obs. \\
\hline 1900 & Mean & Median & & Mean & Median & \\
1910 & 5.40 & 5.00 & 16 & 45.46 & 41.45 & 20 \\
1920 & 5.80 & 5.00 & 17 & 44.48 & 52.75 & 20 \\
1930 & 5.95 & 5.00 & 13 & 59.75 & 66.60 & 20 \\
1940 & 6.45 & 6.00 & 10 & 64.37 & 72.35 & 20 \\
1950 & 6.65 & 6.00 & 10 & 64.16 & 71.55 & 20 \\
1960 & 6.90 & 6.50 & 9 & 71.10 & 87.50 & 20 \\
1970 & 7.20 & 7.00 & 4 & 76.15 & 100.00 & 20 \\
1980 & 9.15 & 8.00 & 2 & 81.88 & 100.00 & 20 \\
1990 & 7.95 & 7.00 & 2 & 86.71 & 100.00 & 20 \\
2000 & 7.25 & 8.00 & 2 & 90.68 & 100.00 & 20 \\
\hline Mean & 7.90 & 7.00 & 2 & 92.51 & 100.00 & 20 \\
\hline \hline
\end{tabular}

Source: Own calculations 
Panel A2: Board composition for selected years, 1900 sample, non survivors

\begin{tabular}{|c|c|c|c|c|c|c|}
\hline & \multicolumn{2}{|c|}{ Board size } & \multirow[t]{2}{*}{ Family CEO } & \multicolumn{2}{|c|}{ Board members outside founding family (\%) } & \multirow[t]{2}{*}{ N. Obs. } \\
\hline & Mean & Median & & Mean & Median & \\
\hline 1900 & 4.93 & 4.00 & 11 & 68.23 & 100.00 & 20 \\
\hline 1910 & 5.33 & 5.00 & 10 & 76.44 & 100.00 & 20 \\
\hline 1920 & 5.92 & 5.50 & 9 & 70.34 & 72.90 & 17 \\
\hline 1930 & 5.82 & 5.00 & 8 & 72.82 & 77.70 & 16 \\
\hline 1940 & 4.86 & 6.00 & 5 & 92.84 & 100.00 & 12 \\
\hline 1950 & 3.50 & 3.50 & 3 & 95.83 & 100.00 & 10 \\
\hline 1960 & 9.67 & 8.00 & 3 & 100.00 & 100.00 & 4 \\
\hline 1970 & 5.50 & 5.50 & 2 & 100.00 & 100.00 & 3 \\
\hline 1980 & 7.00 & 7.00 & 2 & 100.00 & 100.00 & 2 \\
\hline 1990 & 4.00 & 4.00 & 0 & 100.00 & 100.00 & 1 \\
\hline 2000 & . & . & 0 & 100.00 & 100.00 & 0 \\
\hline Mean & 5.06 & & 7.74 & 79.42 & & \\
\hline
\end{tabular}

Panel B: Board composition for selected years, 1960 sample

\begin{tabular}{|c|c|c|c|c|c|c|}
\hline & \multicolumn{2}{|c|}{ Board Size } & \multirow[t]{2}{*}{ Family CEO } & \multicolumn{2}{|c|}{ Board members outside founding family ( $\%$ ) } & \multirow[t]{2}{*}{ N. Obs. } \\
\hline & Mean & Median & & Mean & Median & \\
\hline 1960 & 2.80 & 3.00 & 16 & 43.15 & 41.65 & 20 \\
\hline 1970 & 5.55 & 5.00 & 12 & 66.48 & 77.50 & 20 \\
\hline 1980 & 6.47 & 6.00 & 8 & 74.94 & 86.65 & 20 \\
\hline 1990 & 7.35 & 7.00 & 4 & 82.55 & 100.00 & 20 \\
\hline 2000 & 7.00 & 6.00 & 3 & 83.62 & 100.00 & 20 \\
\hline Mean & 5.83 & & 10.90 & 70.15 & & \\
\hline
\end{tabular}

Source: Own calculations 


\section{Table 5- Separation of ownership and control}

This table reports mean and median separation of ownership and control. Separation is defined as the difference between the proportion of founding family members on the board and family shareholdings. A negative value indicates that there is a greater proportion of family ownership than board representation. Panel A refers to the 1900 sample, and reports results separately for survivors and non-survivors. Panel B refers to the 1960 sample.

Panel A: Separation of ownership and control for selected years, 1900 sample

\begin{tabular}{rrrcccc}
\hline \hline & Survivors & No. of Survivors & Non-survivors & $\begin{array}{c}\text { No. of Non- } \\
\text { survivors }\end{array}$ & Full sample & N. Obs. \\
\hline 1900 & -1.16 & 20 & 5.69 & 20 & 1.86 & 40 \\
1910 & 6.78 & 20 & 2.00 & 20 & 4.67 & 40 \\
1920 & -7.87 & 20 & 9.88 & 17 & -1.00 & 37 \\
1930 & 8.97 & 20 & 14.25 & 16 & 10.91 & 36 \\
1940 & 15.60 & 20 & 6.17 & 12 & 13.16 & 32 \\
1950 & 13.15 & 20 & 4.02 & 10 & 11.04 & 30 \\
1960 & 14.99 & 20 & 0.00 & 4 & 12.45 & 24 \\
1970 & 15.04 & 20 & 0.00 & 3 & 12.60 & 23 \\
1980 & 12.03 & 20 & 0.00 & 2 & 11.13 & 22 \\
1990 & 9.15 & 20 & 0.00 & 1 & 8.71 & 21 \\
2000 & 6.69 & 20 & & 0 & 6.69 & 20 \\
\hline Mean & 8.50 & & 6.94 & & 8.13 & \\
\hline \hline
\end{tabular}

Panel B: Separation of ownership and control for selected years, 1960 sample

\begin{tabular}{rrc}
\hline \hline & Mean & N. Obs. \\
\hline 1960 & -1.52 & 20 \\
1970 & 3.13 & 20 \\
1980 & 6.70 & 20 \\
1990 & 10.50 & 20 \\
2000 & 11.94 & 20 \\
\hline Mean & 6.15 & \\
\hline \hline
\end{tabular}

Source: Own calculations 
Table 6- Takeovers in the U. K., 1919-1939: Target board turnover and dividend changes

This table reports the proportion of target directors that resign after a takeover, the number of target companies where the chairman resigns and the proportion of target companies keeping the dividend constant 2 years prior to the takeover for a sample of 40 takeovers over the period 1919-1939.

\begin{tabular}{lcccc}
\hline \hline Time period & $\begin{array}{c}\text { Proportion of target board } \\
\text { resigning after takeover }\end{array}$ & Chairman resigned & Dividend constant & N. Obs. \\
\hline $1919-1923$ & $5.36 \%$ & 0 & 10 & 11 \\
$1924-1928$ & $33.76 \%$ & 3 & 7 & 12 \\
$1929-1933$ & $16.68 \%$ & 2 & 8 & 7 \\
$1934-1939$ & $57.80 \%$ & 9 & 14 & 40 \\
\hline Total & $30.28 \%$ & 14 & 70 \\
\hline \hline
\end{tabular}

Source: Hannah (1974) and own calculations 


\section{Table 7 - Bid premia in the UK}

This table reports the bid premia for the UK in the twentieth century. Panel A considers 40 UK takeovers over the period 1919-1939 and computes premia as the raw (unadjusted) stock returns for targets over the periods $(-4$ to +1$)$ months and month 0, where month 0 is the announcement month. Panel B refers to the first three hostile takeover bids of the 1950s, as reported in Roberts (1992), and computes premia as in Panel A. Panel C refers to 1,463 UK takeovers in the period 1955-1985, and computes premia as the market-adjusted stock returns for targets over the periods $(-4$ to +1$)$ months and month 0 , where month 0 is the announcement month. The source for Panel C is Franks and Harris (1989).

Panel A-Bid Premia in the U. K.: 1919-1939

\begin{tabular}{lrccc}
\hline \hline & & Months -4 to +1 & Month 0 & Total Market Value \\
\hline Time Period & No. & EW & EW & (£/millions) \\
\hline $1919-23$ & 11 & $-10.02 \%$ & $-3.34 \%$ & 31.5 \\
$1924-28$ & 12 & $+14.69 \%$ & $+0.55 \%$ & 43.3 \\
$1929-33$ & 7 & $-2.45 \%$ & $-1.13 \%$ & 19.0 \\
$1934-39$ & 10 & $+14.84 \%$ & $+0.22 \%$ & 26.6 \\
\hline Mean & & $+4.93 \%$ & $-0.90 \%$ & \\
\hline \hline
\end{tabular}

Source: Hannah (1976) and own calculations

Panel B-Bid Premia in the U. K.: Hostile Takeovers 1953-1958

\begin{tabular}{llcc}
\hline \hline & & Months -4 to +1 & Month 0 \\
\hline Year & Target & EW & EW \\
\hline 1953 & J. Sears & $122.22 \%$ & $90.48 \%$ \\
1958 & Savoy Hotel & $87.00 \%$ & $19.53 \%$ \\
1958 & British Aluminium & $39.53 \%$ & $17.47 \%$ \\
\hline Mean & & $82.92 \%$ & $42.49 \%$ \\
\hline \hline
\end{tabular}

Source: Own calculations

Panel C-Bid Premia in the U. K.: 1955-1985

\begin{tabular}{lcccccc}
\hline \hline & \multicolumn{2}{c}{ Months -4 to +1} & \multicolumn{2}{c}{ Month 0 } & Total Market Value \\
\hline Time Period & No. & EW & VW & EW & VW & (£/billions) \\
\hline $1955-59$ & 151 & $28 \%$ & $25 \%$ & $16 \%$ & $11 \%$ & 0.5 \\
$1960-64$ & 190 & $24 \%$ & $26 \%$ & $18 \%$ & $14 \%$ & 1.4 \\
$1965-69$ & 262 & $27 \%$ & $24 \%$ & $19 \%$ & $12 \%$ & 3.7 \\
$1970-74$ & 196 & $35 \%$ & $41 \%$ & $25 \%$ & $23 \%$ & 2.8 \\
$1975-79$ & 383 & $38 \%$ & $34 \%$ & $30 \%$ & $22 \%$ & 3.8 \\
$1980-84$ & 281 & $27 \%$ & $27 \%$ & $25 \%$ & $30 \%$ & 10.0 \\
\hline Mean & & $30 \%$ & $30 \%$ & $22 \%$ & $19 \%$ & \\
\hline \hline
\end{tabular}

Source: Franks and Harris (1989) 


\section{Table 8 -Incidence of anti-takeover measures}

This table reports the incidence of anti-takeover measures (dual class voting, voting restrictions and insider ownership greater than 50\%) in the U.K in 1950 in Panel A, 1965 in Panel B and 1975 in Panel C.

Panel A - 1950

\begin{tabular}{lcc}
\hline \hline & No of companies & $\%$ of listed companies \\
\hline Commercial and Industrial & 56 & $3.60 \%$ \\
Breweries and Distilleries & 13 & $6.30 \%$ \\
Iron, Coal and Steel & 4 & $1.82 \%$ \\
& & \\
\hline Total & 73 & $3.68 \%$ \\
\hline \hline
\end{tabular}

Panel B - 1965

\begin{tabular}{lccccc}
\hline \hline & \multicolumn{2}{c}{ Static Analysis } & \multicolumn{2}{c}{ Dynamic Analysis (since 1950) } \\
\hline & No of companies & $\begin{array}{c}\text { \% of listed } \\
\text { companies }\end{array}$ & Adoptions & New companies & Delisting \\
\hline Commercial and Industrial & 236 & $11.80 \%$ & 98 & 86 & 4 \\
Breweries and Distilleries & 10 & $10.20 \%$ & 2 & 4 & 9 \\
Iron, Coal and Steel & 3 & $2.21 \%$ & 0 & 2 & 3 \\
& & & & 92 & 16 \\
\hline Total & 249 & $11.15 \%$ & 100 & & \\
\hline
\end{tabular}

Panel C- 1975

\begin{tabular}{lcccccc}
\hline \hline & \multicolumn{2}{c}{ Static Analysis } & \multicolumn{3}{c}{ Dynamic Analysis (since 1965) } \\
\hline & & $\begin{array}{c}\text { New } \\
\text { companies }\end{array}$ & Adoptions & $\begin{array}{c}\text { companies } \\
\text { Dropped }\end{array}$ & Delisting \\
\hline Commercial and Industrial & 145 & $7.25 \%$ & 18 & 7 & $\mathbf{3 2}$ & $\mathbf{8 4}$ \\
Breweries and Distilleries & 6 & $6.06 \%$ & 1 & 0 & 1 & 4 \\
Iron, Coal and Steel & 1 & $2.08 \%$ & 0 & 0 & 1 & 34 \\
& & & & & & \\
\hline Total & 152 & $7.08 \%$ & 19 & 7 & 89 \\
\hline \hline
\end{tabular}

Source: Own calculations 


\section{References}

Becht, Marco, and Colin P. Mayer, 2001. "Introduction" in Barca, Fabrizio, and Marco Becht, (eds.), 2001, The Control of Corporate Europe. Oxford University Press, Oxford.

Chandler, Alfred D., 1990. Scale \& Scope: The Dynamics of Industrial Capitalism. Harvard University Press, Cambridge: MA.

Davies Paul, and Klaus J. Hopt, 2004. "Control transactions", Ch. 7 in Kraakman, Reinier, Gerard Hertig, Paul Davies, Henry Hansmann, and Klaus J. Hopt, The Anatomy of Corporate Law. Oxford University Press, Oxford.

Florence, P. Sargant, 1953. The logic of British and American industry. Routledge \& Kegan Paul, London.

Franks, Julian R., and Robert S. Harris, 1989. Shareholder wealth effect of corporate takeovers. The U.K. experience 1955-1985. Journal of Financial Economics, 23225 249.

Franks, Julian R., and Colin P. Mayer, 2001. Ownership and control of German corporations. Review of Financial Studies 14, 943-977.

Franks, Julian R., and Colin P. Mayer, 1996. Hostile takeovers and the correction of managerial failure. Journal of Financial Economics 40, 163-181.

Franks, Julian R., Colin P. Mayer, and Stefano Rossi, 2004. Ownership: Evolution and regulation. Mimeo, London Business School and Saïd Business School, University of Oxford.

Hannah, Leslie, 1974a. Mergers in British manufacturing industry 1880-1918. Oxford Economic Papers 26, 1-20.

Hannah, Leslie, 1974b. Takeover bids in Britain before 1950: An exercise in business 'pre-history'. Business History 16, 65-77.

Hannah, Leslie, 1976. The rise of the corporate economy. Methuen, London.

Hart, P.E. and Prais, S.J., 1956. The analysis of business concentration: a statistical approach. Journal of the Royal Statistical Society 119, 150-191.

Landes, David, 1965. "Technological change and development in Western Europe 1750-1914”, in H.J. Habakkuk and M. Postan (eds), Cambridge Economic History of Europe, Vol VI: The Industrial Revolution and After. Cambridge University Press, Cambridge.

May, Wilfred, 1939. Financial regulation abroad: The contrasts with American technique. Journal of Political Economy 47, 457-496. 
Michie, Ranald C., 1999. The London Stock Exchange: A History. Oxford University Press, Oxford.

Rajan, Raghuram G., and Luigi Zingales, 2003. The great reversals: The politics of financial development in the $20^{\text {th }}$ Century. Journal of Financial Economics, 69, 5-50.

Roberts, Richard, 1992. Regulatory responses to the rise of the market for corporate control in Britain in the 1950s. Business History 34, 183-200. 